\title{
Acquiring Scientific and Technological Proficiency: State of Science Education in Bangladesh
}

ISSN: 2311-8636 (Print)

ISSN: 2312-2021 (Online)

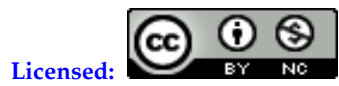

Source of Support: Nil

No Conflict of Interest: Declared

*Email for correspondence: dulal03@gmail.com

DOI:

https://doi.org/10.5281/zenodo.3355651

\section{Sabina Yeasmin ${ }^{1}$, Md. Dulal Mahmud ${ }^{2 *}$}

${ }^{1}$ Professor, Bangladesh Open University, Gazipur-1705, BANGLADESH

${ }^{2}$ Lecturer, Bangladesh Open University, Gazipur-1705, BANGLADESH

\section{ABSTRACT}

Developing scientific values in students' mind is the goal of science teaching. Bangladesh, of late, has adopted various strategies to educate the people and mainly the children. There are still many challenges for the country to attain an acceptable standard of education. Science education here in Bangladesh is in a state of crisis. The enrolment for science studies in the country shows a sharp decline over the past few years. This discipline, what once used to be the most sought after subject at secondary, higher secondary and tertiary levels in the country, is losing its appeal in an alarming shift of choice. Indeed it is important know what the obstacles are and how they are removed within a stipulated short period. This paper aims to present the current situation of Bangladesh in terms of science and technological development in the education sector. There is no alternative of a scientifically and technologically literate workforce as the future economy will also be science i.e. ICT based.

Keywords: Science, literacy, education, technology, enrolement

\section{INTRODUCTION}

Human civilization, started with the discovery of fire for light, heat, and cooking, today has reached to its peak through step by step and research on science has not been stopped yet. Science and Technology (S\&T) have an undeniable impact in all sectors of national and international affairs. It has nourished through centuries that it has, at last, reached the highest peak of perfection, beauty, and brilliance. It is an outcome of human culture that speaks eloquently of men's ceaseless endeavors for higher and higher attainments. Given its need and importance, one can in unequivocal terms conclude that S\&T enjoys global popularity now as it did in the past. But why? Because it is a dynamic and forceful discipline as one can grasp, learn, and use in everyday life. And that is why science now occupies a unique place of dignity and earns the admiration of the world people leading them on, as if, to unveil its mysteries.

S\&T is growing very quickly but, scientific and technologic development requires the development of science education. In today's knowledge-based society, it has become an 
integral part of our everyday lives. Science brings reason and enlightenment and provides ideas for technological innovations, which improve the quality of life. Scientific advances revolutionize our understanding of the living world, just as the concepts and representations formulated and forged during a slow process, throughout history, enable us to perceive and think of ourselves as human beings. Most experts consider science as universal and scientific knowledge is having privileged status based on the reliability of the methods of science. The development of modern society depends to a large extent on the nature and standard of higher education in general with particular emphasis on S\&T. There is a direct relationship between science and epistemology. Without the knowledge of science epistemology cannot be understood.

In this age of high technology and globalization, it is expected that to achieve sustained economic growth, developing countries need to capitalize on intelligent and judicious use of existing resources and intellectual capital. This is especially true for a highly populous country with limited land and negligible reserves of natural resources, such as Bangladesh. Bangladesh, one of the most densely populated countries in the world, extends over an area of 147,570 sq $\mathrm{km}$ with a population of around 162.7 million, often half of which are women (Ministry of Planning, 2018). The country faces the challenge of becoming a learning society, and ensuring that its citizens are equipped with knowledge of S\&T, skills and qualifications they will need in this century; so that with insignificant natural resources and a huge population on a small piece of land, through S\&T means, it can be developed.

\section{Statement of the Problem}

Science education here in Bangladesh presently is in a state of crisis. Though many scientists, born and educated in Bangladesh but now living in western countries, have contributed and are still contributing significantly to the advancement of S\&T. Our society is in increasing need of S\&T based professionals to carry the nation into a technologically driven future. As a society, if we are increasingly ignorant about science, and if that continues, it is going to cost us. Now in the context of what reads above it is essential that a nation to have its seat of dignity in the comity of nations has to stress the need of learning science and make gainful use of it. Bangladesh though it is predicted to be one of the rising economies in the next two decades, has two major challenges, poverty and unemployment. Arguably, more than 40 percent of the population lives in poverty, and the unemployment rate is one of the highest in the world. But these challenges can be very well addressed because of the changing demographics of the developed world by achieving excellence in S\&T education.

Ours critical situation in the matter of learning and teaching science, and we cannot force it out. We must not forget that S\&T shall stay in Bangladesh, no matter we want it or not. It shall not stay for its own sake but the sake of our individual, national, and international interests. But of late science started to be neglected. By undermining science thus, we painfully noted the fall of a great discipline from a magnificent state. Such deterioration has deterred the progress of science and diminished its enthusiasm in learning and cultivating the technological progress. The result of such position is, by and large, detrimental to the nation. Our students who will take the lead of the country in the future are disinterested in science. It is time that we understand the need, and squarely meets the need. The question naturally arises how to meet. Obviously, the very aversion to learning science is the main obstacle, and this obstacle has to be removed in no time. Once, we 
agree to this concept; we must know what the obstacles are and how they removed within a stipulated short period.

There is no alternative to the culture of science to build an enriched nation. So far we have failed to address the problem of making science events popular among science students and scientists, at least as popular as entertainment or sports; then the sponsorship even from technology-driven companies who would prefer spending their money in areas other than science. The future of Bangladesh lies in the knowledge but our ability to generate new knowledge and use of innovatively depends upon a scientifically literate population.

The broader objective of this article is to explore the status of science education in Bangladesh including, its prospects and challenges in general and finding recommendations for a way out in particular.

\section{LITERATURE REVIEW}

Science is a systematic process of learing about the world by observation, testing and discovery, which is essential to develop solutions to the problems we face. Bangladesh faces considerable challenges concerning illiteracy, secondary and tertiary education as well as in the area of science education; as within the current climate in Bangladesh, S\&T education receives less priority in policy formulation (Alam et al. 2009). Siddique and Rahman (2007) observes there are differences among different groups of citizens on what should be the goals of 'science education' in Bangladesh. Some people call for using science education as a tool for removing superstitions and religious extremism from the society whereas some argued for a religious focus of science education. Ashraf (2008) and Choudhury (2009) finds science, what once used to be the most sought after subject at secondary, college and university levels in the country, is losing its appeal in an alarming shift of choice.

Nowadays, science education throughout the world promotes 'scientific literacy' which has been characterized as consisting of four inter-related aspects: contexts, knowledge of and about science, competencies, and attitudinal aspects of science (Akhter, 2011). Alam (2008b) observes that the number of female students in science at higher education is even less than 20 percent; whereas UNESCO (2008) finds the under representation of women in S\&T as a worldwide issue. Kaykobad (2012) opines that the academicians have immeasurably failed to play their role in motivating due appreciation of the society for knowledge works. For this students interest in science education decreases gradually. If such a trend of science education continues, the country could turn science less in the near future. However, Siddique and Rahman (2007) sees that in line with recent global trends, the science curriculum in Bangladesh sets a goal of promoting selected values through teaching science. But Sarkar (2011) finds the classroom science teaching here is textbook oriented and examination based, where students are assessed by the items taken from the textbooks and tests often demand answers copy from the textbooks. However, it is encouraging that under such a situation, the need for science education as well as faster technological development is increasingly felt in the country.

\section{Methodology}

S\&T education needs to be developed to confront the challenges of the 21st century. It is time to make aware the society and policy makers to seriously consider this issue. Thus in doing so, the article takes to endeavor to answer a few questions. Why is Bangladesh 
labeled as a least developed country lagging in S\&T? What can we learn from the examples of other countries? How can science education system in Bangladesh play a constructive role for sustainable development by finding solutions to the challenges facing the country? What is the present status of science education in Bangladesh, and what contributes most to the decline of the quality of science education and student enrolment? What are the challenges and way out to bring back the days of glory of science education in Bangladesh? This article has been developed based on both primary and secondary sources of data. The primary data were collected from the targeted respondents by using a semi-open ended questionnaire. Uses of different tools of participatory research were made to collect both qualitative and quantitative data, and the data were processed in a scientific manner. Various statistical tools were used to analyze the quantitative data and for the analysis of the qualitative data, this study mostly relied on discourse analysis.

\section{Study Discussion}

\section{Role of Education}

A Chinese proverb regarding 'education' goes thus "If you want to think one year ahead, plant rice; if you want to think ten years ahead, plant trees; but if you want to think hundred years ahead give education to people (Billah, 2012)." Education is the key to creating, adapting, and spreading knowledge for technological transformation in the network age (Alam, 2009). It is considered as one of the basic requirements for human resources development and plays a vital role in the development of a nation, and many countries made required progress through education. Nevertheless, some of them also failed to retain the development achieved since these countries failed to supply the required skilled workforce.

Althusser (1971) sees the role of education as ideological and argues that the main role of education in capitalist society is the reproduction of an efficient and obedient workforce, which is achieved through formal education. He believes that the education system has taken over from the Church as the main agent of ideological transition essential to the maintenance of the capitalist economic system. On the other hand, Subrahmanian (2002) observes that the goal of universal basic education in developing countries has grown out of the recognition of its importance for equipping nations and individuals with the capacities and tools required responding to the demands of changing economic structures. The World Education Forum in Dakar in 2000 emphasizes that despite the priority given to the education for women and girls, real progress has been much slower than expected.

\section{Science and Technology Education}

Few basic inventions of science initiated the industrial revolution of Europe in the 18th century. All these inventions provided modern lifestyle to the people within a very short time, by changing the long backwardness of society. Not only had that, for the expansion of knowledge, the people of Europe turned out to be rational and self-conscious. South Korea has emerged as the world's third-largest economy through investment in S\&T without having natural resources. India is a significant next-door example of how to develop on S\&T.

Scientific and technological know-how, not the number of natural resources, determines the development of a country. Much of the relevancy of science to human being and society arises by way of technology, which is the bedrock of scientific investigation. Science brings reason and enlightenment, provides ideas for technological innovations, 
and improves the quality of life; whereas technology, in turn, provides science with new tools and instruments for doing research, for the storage and dissemination of information and for stimulation of further research. However, building scientific capacity is much more than just technology transfer.

While higher education is an essential prerequisite for the development of knowledgebased economies, both academic excellence and sustainable development are critically dependent on scientific proficiency and a strong technology base. Science is no longer confined within the borders of a single nation. Mobility of scientists is now a universal character of science. There is increased cooperation and exchange of information between scientists of different countries -- developed and underdeveloped alike. S\&T complement each other via complex, two-way interaction. In today's knowledge-based society, S\&T, as we are constantly reminded, have become an integral part of our everyday lives. The case of developed nations, the leading factors responsible for economic development are innovations through scientific knowledge. Since the 1950s, several reform movements brought revolutionary changes in the science curriculum of western countries. The countries that achieved sustainable development have given a high priority to S\&T education in formulating education policy. The underlying reason for the inequity between the developed and developing nations is due to the widening gap in S\&T.

Public challenges to science from several directions have gained much air space in recent decades, and demand response in science education. Postmodernist critiques of science, attacking its claim to high-status knowledge, have been hotly pursued and contested in what has become known as the 'science wars' (Ziman, 2000). Feminist and post-colonial critiques of science also challenge global science research and development practices and their representation in science education. The need to accommodate indigenous perspectives in science curricula in many countries has raised questions about the nature of science and its cultural antecedents (Aikenhead, 2001).

\section{Education in Bangladesh}

There has been a remarkable development in education in the last 47 years in Bangladesh though it is yet to achieve the quality in all tiers of education. The country conforms fully to the Education for All (EFA) objectives that began in 1990 in Jomtien and the Millennium Development Goals (MDG). She is also a signatory to the Dakar Declaration of 2000. Her commitment to the six Dakar goals is backed by conviction and an all out effort. Again Article 17 of the Bangladesh Constitution provides that all children between the ages of six and ten years receive a basic education free of charge. The educational system in Bangladesh is three-tiered and highly subsidized. The government of Bangladesh operates many schools in the primary, secondary, and higher secondary levels. However, the education system of the country suffers from a very low level of external and internal efficiencies and is mostly non-responsive to the employment market demand (Alam, 2008a).

Budgetary allocation for the education sector has increased over the years in Bangladesh, the share of this budget as a percentage of the total budget. A sum of Tk79,486 crore has been proposed for the Education and Technology sector for 2019-20 fiscal year - Tk13,213 crore more than the budget passed last year, which was Tk 66,273(Dhaka Tribune, 2019). Since Bangladesh's independence, this is the highest amount allocated for the education sector. It is $15.2 \%$ of the total drafted budget (Figure 1). 
Figure 1: Bangladesh National Budget 2019-20

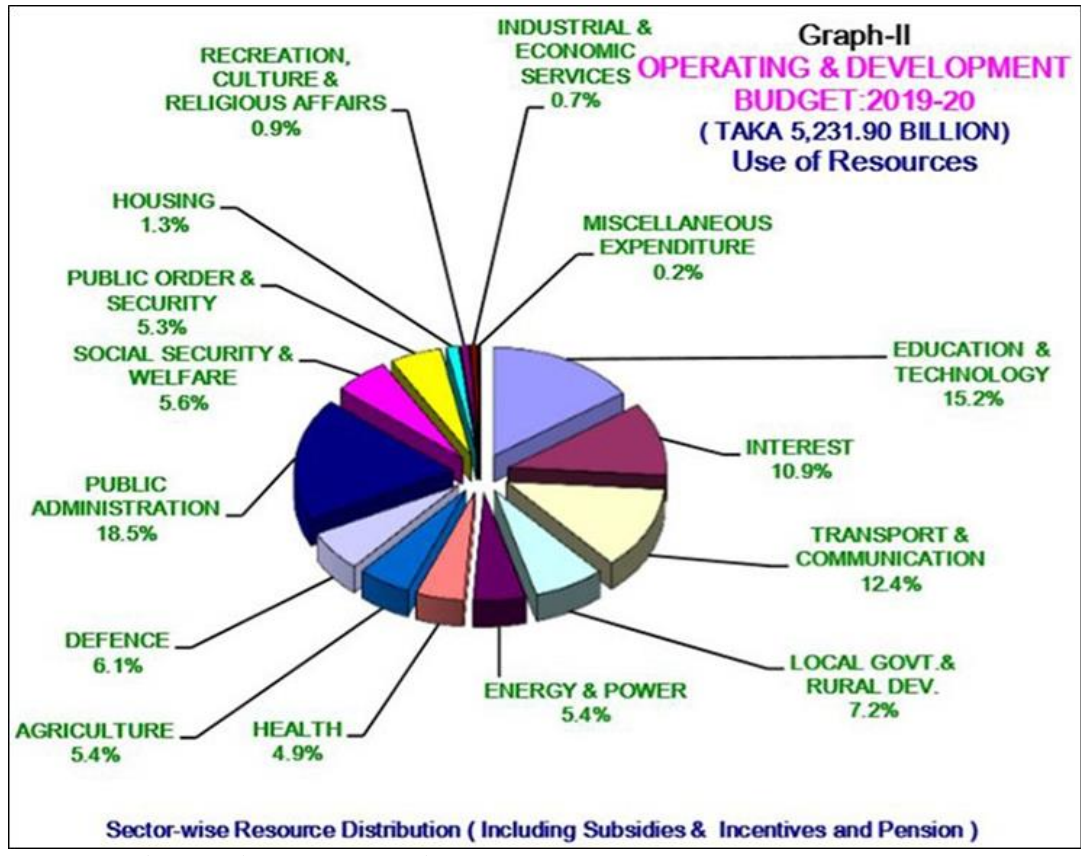

Source: The Daily Star, 24 July 2019

The amount allocated to the Education and Technology sector is 3.04\% in Gross Domestic Production (GDP), where as neighbouring country India allocated only $2.05 \%$ (Dhaka Tribune, 2019). The Dakar Declaration of UNESCO sets a 20 percent budget goal and prescribes that at least 6 percent of a country's GDP be allocated to education.

In seeking to meet the education objectives, Bangladesh realized that multiple strategies and methods had to be adopted. Bangladesh has done relatively well in various aspects of education during the past two decades. Improvements are noticeable in both primary and secondary education. However, a notable but unfortunate feature of educational development in the country is the inequity that exists between different groups in the population. There are inequities between school types, streams of education, residence (urban-rural, districts), ethnicity and socio-economic backgrounds (CAMPE, 2011).

Since the independence of Bangladesh, there have been as many as five education commissions. After the liberation of the country, a national educational commission led by renowned scientists Dr. Muhammad Qudrat-i-Khuda was formed in 1972. The last commission was formed in 2010 headed by National Professor Kabir Chowdhury, where prominent scientist like Professor Dr. Zafar Iqbal worked as a member. The output of this commission 'The National Education Policy 2010' emphasizes to establish mandatory core subjects for primary level education: Bangla, English, Mathematics, Bangladesh Studies, Social Environment and Climate Change, ICT, and Science; and standardization of teachers' qualification including more training for them. However, currently there is little motivation to become a teacher while the social status of teachers is declining. Recruitments, on the other hand, are generally based on nepotism and partisanship. Once recruited, nothing can jeopardize the job. Someone does not have to prove anything and yet will get promoted in course of time. 


\section{Current Situation of Science Education in Bangladesh}

Like many other countries in the developing world, science education in Bangladesh tries to follow the western world in reforming the system. Since the independence of Bangladesh in 1971, this has been reformed several times following western models. The reforms included development of new curricula, training of teachers, and the publication of new government sponsored textbooks. However, stakeholders remained unhappy with the outcome of these reforms. Due to the lack of academic research by science educators, the reasons for the unsatisfactory outcome of the reforms have not been identified.

The education system of Bangladesh is comprised of a mix of heterogeneous providers. A variety of schools operates within the country; government runs schools, privately run schools and madrasah, English medium schools, schools run by NGO's and Kindergarten schools (Ministry of Education ,2017). Science education starts from primary school (Grade III) in Bangladesh. In the beginning, student studies basics on natural sciences, such as life of trees, flowers, etc. From Grade III to Junior high school (Grade VIII) student studies the basic composite science subject Physics, Chemistry, Biology and general Mathematics. From Grade IX students are divided into the following groups on the basis of their interest: biological science group, physical science group, arts group, and commerce group (Miah, M. B. 2011). Science subjects are also taught in Bangladesh Open University and Madrasha (religious school), but on a limited scale where basic Physics, Chemistry, Biology and Mathematics are taught. According to BANBEIS Educational Database, Bangladesh Education Statistics 2018(New) there are around 20465 secondary schools at present in Bangladesh and total students at Class X around 1719959, in which science students around 525099 (Table 1); Most of the students come from farmer and labor's family.

Table 1: Number of students by Stream and Management in the Secondary Schools 2018

\begin{tabular}{|c|c|c|c|c|c|c|c|c|c|}
\hline \multirow{2}{*}{$\begin{array}{c}\text { Type of } \\
\text { Institution }\end{array}$} & \multirow{2}{*}{$\begin{array}{c}\text { Manage } \\
\text { ment }\end{array}$} & \multicolumn{4}{|c|}{ Class IX } & \multicolumn{4}{|c|}{ Class $\mathrm{X}$} \\
\hline & & $\begin{array}{l}\text { Human } \\
\text { ities }\end{array}$ & Science & $\begin{array}{l}\text { Business } \\
\text { Studies }\end{array}$ & Total & $\begin{array}{l}\text { Human } \\
\text { ities }\end{array}$ & Science & $\begin{array}{l}\text { Business } \\
\text { Studies }\end{array}$ & Total \\
\hline $\begin{array}{l}\text { Junior } \\
\text { Secondary } \\
\text { School }\end{array}$ & Private & 11623 & 6380 & 7123 & 25126 & 8158 & 5372 & 5818 & 19348 \\
\hline \multirow{3}{*}{$\begin{array}{l}\text { Secondary } \\
\text { School }\end{array}$} & Public & 33751 & 54974 & 19102 & 107827 & 31703 & 55336 & 21085 & 108124 \\
\hline & Private & 737577 & 360759 & 265764 & 1364100 & 704279 & 381880 & 310506 & 1396665 \\
\hline & Total & 771328 & 415733 & 284866 & 1471927 & 735982 & 437216 & 331591 & 1504789 \\
\hline \multirow{3}{*}{$\begin{array}{l}\text { School and } \\
\text { College }\end{array}$} & Public & 3767 & 7089 & 3225 & 14081 & 3073 & 6830 & 2941 & 12844 \\
\hline & Private & 66664 & 75781 & 43141 & 185586 & 62615 & 75681 & 44682 & 182978 \\
\hline & Total & 70431 & 82870 & 46366 & 199667 & 65688 & 82511 & 47623 & 195822 \\
\hline \multirow[t]{3}{*}{ Total: } & Public & 37518 & 62063 & 22327 & 121908 & 34776 & 62166 & 24026 & 120968 \\
\hline & Private & 815864 & 442920 & 316028 & 1574812 & 775052 & 462933 & 361006 & 1598991 \\
\hline & Total & 853382 & 504983 & 338355 & 1696720 & 809828 & 525099 & 385032 & 1719959 \\
\hline \multicolumn{2}{|c|}{$\%$ Stream } & 24.98 & 14.78 & 9.90 & 49.66 & 23.70 & 15.37 & 11.27 & 50.34 \\
\hline
\end{tabular}

Source: BANBEIS Educational Database, Bangladesh Education Statistics 2018(New)

All schools are divided into 3 categories on the basis of availability of science facilities as follows (Table 2).

Although there are laboratories in some of the secondary schools, there is no laboratory assistant, which is very necessary. Laboratory assistant could help the students by showing the technique of using the equipments of the laboratory. 
Table 2: Different Categories of Secondary Schools with Science Facility

\begin{tabular}{|l|l|l|}
\hline $\begin{array}{c}\text { 'A' Category (900-1000) } \\
\text { Schools } \\
\text { (generally in big cities) }\end{array}$ & \multicolumn{1}{|c|}{$\begin{array}{c}\text { 'B' Category (7800-8200) } \\
\text { Schools (in the developing } \\
\text { cities and some rural areas) }\end{array}$} & \multicolumn{1}{|c|}{$\begin{array}{c}\text { 'C' Category (4500-5000) } \\
\text { Schools } \\
\text { (mostly in the rural areas) }\end{array}$} \\
\hline Laboratory. & $\begin{array}{l}\text { One multi-purpose room } \\
\text { (laboratory, recreation, etc.). }\end{array}$ & Very small Laboratory. \\
\hline $\begin{array}{l}\text { Equipment and } \\
\text { Chemicals. }\end{array}$ & $\begin{array}{l}\text { Few Equipment and } \\
\text { Chemicals. }\end{array}$ & $\begin{array}{l}\text { Almost no Equipment and } \\
\text { Chemicals. }\end{array}$ \\
\hline $\begin{array}{l}\text { 5-7 Science Teachers per } \\
\text { School. }\end{array}$ & $\begin{array}{l}\text { 2-4 Science Teachers per } \\
\text { School. }\end{array}$ & $1-2$ Science Teachers per School. \\
\hline Good Library. & Small Library. & Very few books are available. \\
\hline
\end{tabular}

Source: Miah, M. B. 2011

Therefore, in spite of having equipment and chemicals, there is no use of scientific experiment. Generally, the science teacher takes the laboratory classes. In general, a science teacher takes 5-6 classes per day, which affects their ability to teach efficiently. That is why all the science courses are being taught only in the class room at this level. However, after completion of the SSC examination, there is a compulsory practical class (one per week) at the laboratory for all the science subjects. Although it is compulsory, there is still very little use of all the scientific equipment and chemicals due to lack of skilled laboratory assistant. In this way, most of the equipments and chemicals are wasted. However according to BANBEIS Educational Database, Bangladesh Education Statistics 2018(New) in secondary school level technological support and facilities over the country such as multimedia $(78.63 \%)$, computer facility $(89.24 \%)$ and internet facility $(80.8 \%)$ much increases before few years. But the numbers of science teachers are much lower than humanities teachers.

S\&T is increasingly recognized to be central to both the origins of sustainability challenges, and to the prospects for successfully dealing with them. Development plans of Bangladesh have emphasized science and technological research to develop technologies through the adoption of imported technology as well as the development of indigenous ones. A 'National Science and Technology Policy' has recently been formulated and adopted by the Government. It has laid down the directions for $S \& T$ activities and research, institutional and manpower development.

While enrolment for science studies shows a sharp decline over the past few years, quality of science education also took a slide during the same time with an evident dearth of quality teachers. So the country desperately needs more science graduates as human resource, the quality of science education. In a world of global market competition, the secondary level education has become a part of basic education and the secondary schools are vested with the responsibility of imparting knowledge, skills and attitudes essential for the individuals to fit into society. A recent study of BANBEIS shows that a number of science students in decline as more and more opt for humanities education (Table 1). But the HSC or higher level total number of science students gradually decreases than humanities and business studies.

But even in colonial days, Bengalis like Jagdish Chandra Bose, Satyen Bose and Meghnad Saha proved commendable science skills. Institutional support is also essential for scientific innovation. Bangladesh has meritorious students aplenty but lacks such support. According to educationist Professor Jamilur Reza Choudhury (Vice -Chancellor, 
University of Asia Pacific), in our neighboring country, the government provides scholarship to the youngsters who are interested in science from primary to postgraduation levels (The Daily Star, 3 March 2012). So for our survival in the $21^{\text {st }}$-century competitive world, we must follow their footprint and invest heavily in human resources giving priority to S\&T. The country has no alternative to using science education as a tool for improving the living standards of the people and for dealing with the economic and environmental challenges it faces.

\section{Survey Result}

The focused target group of the study was both students and other stakeholders. Among a total of 60 respondents, 38 persons $(63.33 \%$ ) were male with 22 persons (36.33\%) female (Table 3$)$.

Table 3: Gender of the Respondents

\begin{tabular}{|c|c|c|}
\hline Gender & Total & Percentage (\%) \\
\hline Male & 38 & 63.33 \\
\hline Female & 22 & 36.66 \\
\hline Total & 60 & 100 \\
\hline
\end{tabular}

Source: Fieldwork, 2018

Table 4: Age of the Respondents

\begin{tabular}{|c|c|c|}
\hline Gender & Total & Percentage (\%) \\
\hline Below 18 years & 32 & 53.33 \\
\hline 18-40 years & 17 & 28.33 \\
\hline 41 years \& above & 11 & 18.33 \\
\hline Total & 60 & 100 \\
\hline
\end{tabular}

Source: Fieldwork, 2018

Out of total 60 respondents, 32 persons (53.22\%) were from the age group of below 18 years, $17(28.33 \%)$ from the age group 18-40 years and $11(18.33 \%)$ were from the age group 41 years and above (Table 4 ).

The study revealed that 7 persons each $(11.666 \%)$ blamed less job facility, poor quality of teachers, poor teaching methodology, inconsistent curriculum, poor quality of textbooks, poor salary of teachers and lack of motivation respectively, and 11 persons $(18.333 \%)$ cited other reasons (Figure 2).

Figure 2: Causes of Decline of Science Education

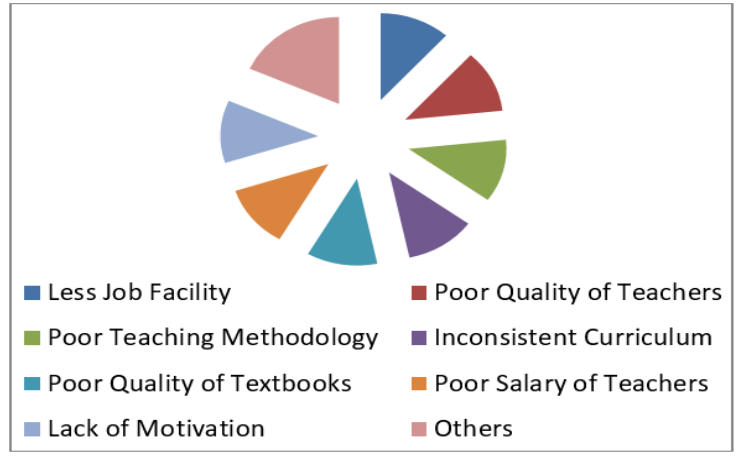

Source: Fieldwork, 2018 


\section{Focus Group Discussion}

To get a clear picture of the overall situation an FGD was conducted with 12 people, among which 6 students were presents (Table 5).

Table 5: Participants of FGD

\begin{tabular}{|c|c|c|c|}
\hline Participants & Students & Other Stakeholders & Venue \\
\hline 12 & 6 & 6 & Peoples' University of \\
& Bangladesh, Asad \\
& $\begin{array}{c}\text { (Science-4 \& Non-Science-2) } \\
\text { Secondary Level-2; } \\
\text { Higher Secondary Level-2; } \\
\text { Under Graduate Level-1; } \\
\text { and Post Graduate Level-1 }\end{array}$ & $\begin{array}{c}\text { Guardian-1; } \\
\text { Teacher-3 (Science-2 \& } \\
\text { Non-Science-1); } \\
\text { Govt. Official-1; and } \\
\text { Civil Society Member-1 }\end{array}$ & $\begin{array}{c}\text { Muhammadpur, } \\
\text { Dhaka-1207 }\end{array}$ \\
\hline
\end{tabular}

Source: FGD, 2018

\section{FINDINGS}

- Over the last few decades the worlds have seen a remarkable economic growth. With this growth, the need and opportunity for new research has also grown by leaps and bounds. Some of this is fundamental, some applied and much of it is interdisciplinary. The institutional structure and government support needed to build and sustain world-class research capability do not yet exist in Bangladesh.

- In the name of globalization and for neo-liberal economic policy, multi-national companies are penetrating the country with their products, which has perhaps increased students' interest in business studies as even students with strong skills in physics, chemistry, and mathematics are opting for such discipline.

- $\quad$ The S\&T proficiency required for the objective of reaching middle-income status is very much dependent on excellence in postgraduate research and innovation.

- Science is related to research. But it lacks practical application in the country as there is the absence of required research institutions in the country. There are fewer sciencebased jobs in the country and most industries in the country do not have R\&D facilities. The savvy state of our industries, including ICT, has resulted in the setback of science enrollment.

- Science education is losing its importance because of the teaching methodology and teachers also cannot inspire the serious and meritorious students to take up science for their studies. Science education is regarded as difficult and only attracts top students in schools and colleges. Even students with strong skills in physics, chemistry, and mathematics are opting for business studies.

- Science has become a subject of terror for students nowadays and it is essential to remove the fear of science from the students through building a platform of science in participation with students and researchers like that of Science Olympiad.

- Science education is made more difficult by poor and unattractive teaching and too much unnecessary workload with poor or no laboratory facilities. As a result, enrollment in secondary and post-secondary science has steadily fallen over the last several years. 
- The societal changes have profound implications for science education in the country. But science students are opting for non-science subjects for their higher education because of demand in the job market, indicating the poor priority is attached to science education.

- The present scenario of science education in secondary schools, particularly of rural areas is horrifying. Lack of brilliant teachers and school infrastructure including laboratory facilities and lack of subject oriented job after completing the education have been identified as the major issues for declining science in school level education. As such more students are opting for business education as new commercial institutions like bank, insurance and other financial service providers are coming up. Besides, some go on to study humanities to complete the courses with less effort and expenses as those learners also lack confidence and motivation to study science.

- In the B and C category secondary schools there is almost no scientific equipment and chemicals are available.

- The curricula and syllabi as are prevailing are not apt to create interest in learning science. Students are afraid of science because of its hard and non-interesting contents. Science has been included even at the primary stage with hard contents that even many teachers could not understand those let alone the students.

- We have been unable to impress young students with the beauty and joy of science. Science textbooks are not written with the aim of creating inquisitiveness in children, nor for their enjoyment and thus fail to fire a spirit of inquiry. The intermediate level science curriculum is not consistent with secondary level.

- This trend of decline in science education is noticed also in the universities. In a typical private university, more than half of the students are enrolled in BBA program because it is easier to get good grades and then good jobs. More so most of the private universities in the country offer business program but rarely any basic science subjects (Alam, 2008b; Alam and Khalifha, 2009).

- Some of the problems identified as common in both secondary and higher science education include lack of laboratory space, lack of funding, and inexperienced and fewer qualified teachers with poor salaries and lack of motivation.

- One important way for students to find joy in science is through commonplace scientific experiments. By directly observing cause and effect students internalize knowledge. However, experiments are not emphasized in schools and colleges, partially due to insufficient funds for purchase of scientific instruments and constructing laboratories.

- Poor teaching quality and lack of infrastructures are also responsible for the declining number of science students. Even many teachers do not clearly understand science and thus fail to make the students understand their lessons properly in classrooms.

- Under the existing system, one needs private coaching to study science in the country, which can be afforded only by the affluent as it is expensive. Only a small fraction of students get the chance to study medicine and engineering or even to study in universities. 


\section{RECOMMENDATIONS}

Bangladesh needs S\&T not simply to boost its pride, but as the primary means for economic and social development of the country. The recommendations are as follows:

- The country has no alternative to using science education as a tool for improving the living standards of the people and for dealing with the economic and environmental challenges it faces.

- It is, by now, we think, clear enough that science is a need-an unavoidable need both for the individual and for the nation as a whole. It has definite impacts in socioeconomic fields as well as in the fields of culture, trade and commerce. The importance and glory of science as it had been in the past decades has to be restored.

- The basic necessities of life for the citizen can be achieved by strengthening the research and development $(R \& D)$ capabilities of the nation in S\&T.

- Our education policy is mainly examination-oriented that evidently does not create quality. Mere pass and good results are what the learners aim at. This is not conducive to realizing the objects of education in general. A comprehensive, clear and realistic policy of education with particular emphasis on science is needed. In addition, there should be an appropriate national science policy.

- $\quad$ Since postgraduate research in the scientific disciplines is extremely expensive, quality must take precedence over quantity and to be internationally competitive, focused primarily on national objectives and adequately funded.

- The availability of skilled and capable teachers having appreciable bias in science is a problem. It is no denying the fact that good education is possible in the hands of good teachers.

- Recruiting quality teachers and building capacities of the existing ones through elearning using ICT based materials, and for regular organizing of science weeks and science fairs can improve the existing situation.

- Salary and other benefits of teachers should be given due consideration and science graduates need to be motivated to become teachers.

- Appropriate training should be imparted to the teachers to make them capable of teaching the respective subjects of science discipline. Possible avenues should be explored so that the teachers while undergoing training should try to remove the apathy of the students to learn science and infuse a spirit of inclination in them for science.

- There is an urgent requirement of building up laboratory and other infrastructures. Required equipments and chemicals need to be supplied to the B and C category secondary schools to have better scientific education.

- Academic supervision is also required to get better result from the teachers. To have better knowledge on science subjects, it is understood that laboratory assistant is necessary in all the schools.

- The interest of learning science is seriously lacking among the students and the want of atmosphere conducive to learning of science is a problem. These are to be adhered to and carefully avoided. 
- A learner-centered approach to teaching and learning should seek to ensure that students are regularly engaged in practicing science rather than memorizing without understanding the contexts of the textbooks.

- The syllabus of the primary and secondary levels should be prepared in such a way that all students could conceive at least 40 percent of its contents without the help of any teacher.

- It is more important to write good science books making it simplified and attractive. Scientific instruments from indigenous materials may be used in order to reduce the investment.

- Competitive events and appropriate campaign should be launched at a regular interval in schools to popularize science education among children. We need to cultivate the students' interest in science through communicating the excitement and beauty of science to the public, including the kids in primary schools. They need to be told how science impacts our lives.

- The Government should provide scholarship to attract more students to science studies. Scholarships should also be provided for young faculty members for higher studies and research.

- The science curriculum should be updated to make it attractive and enjoyable to the learners. It must be need based and students should be encouraged to scientific ways of thinking.

- SSC and HSC science curricula should be coordinated, so students are prepared enough to tackle higher level of science when they enter colleges after graduating from high schools. In fact a better coordinated science curriculum is required at every level of the education system.

- The entire process of learning science should have a job oriented aim. Once it is made learner-oriented, it will be most effective as a proper mechanism for job-oriented end in the national and international situations. Steps should be taken to create more jobs for the science graduates and to do so, the country has to be production-oriented and the labor market should be expanded.

- The government and the University Grants Commission should aim to strengthen existing teacher training colleges and polytechnic institutes, and convert at least some of the colleges under the National University into institutions for training more science and mathematics teachers, nurses, paramedical personnel and agriculture extension workers. Conditions should be created so that these professionals are accorded proper status and respect in the community.

- A substantial quota of fully-funded seats in colleges should be reserved for rural students, including medical and nursing students, who should give an undertaking that they will work for a specified time in the countryside. Appropriate positions should be created in partnership with the private sector, and attractive salaries and other incentives should be provided for employment outside the big cities.

- Because of paucity of funds, higher education in Bangladesh has to be need-based and predominantly S\&T oriented. 
- Locally relevant and multidisciplinary science curricula need to be developed to produce sufficient numbers of trained personnel required to meet the socio-economic needs of Bangladesh and its people, especially those living in the rural areas.

- A national science convention and similar events at district levels should also immediately be organized.

- A terrestrial television channel may be dedicated to broadcasting educational programs, which will help both teachers and students by reducing the latter's dependence on private coaching centers.

- Promoting need-based scientific research based on intellectual competence and popularize science studies by offering a rewarding career to students to achieve faster economic growth.

- Encouraging science researchers to become entrepreneurs.

- $\quad$ The Government should take necessary step for high-speed the internet service all over the country.

- The Government can create a system that provides science syllabus oriented digital contents i.e. class lecture through internet.

- Last but not the least, a commitment of the government to create an S\&T-driven economy to face challenges of the $21^{\text {st }}$ century is an utmost priority.

\section{CONCLUDING REMARKS}

The effort to bring back the glory of science education in the country has been envisaged as the timeliest measure to restore the importance of science in our country. One can hardly deny the role science plays in the modern world. It helps the nations making steady progress in all walks of life. To keep pace with the progress and prosperity in the comity of nations, science can help us enormously. To become a middle-income country, Bangladesh must become proficient in S\&T. But the state of science teaching in schools and colleges in Bangladesh is far from satisfactory. So the urgent need for bringing back science education to the mainstream cannot be over emphasized. The reason to make this effort is not simply the loss or gain of human potential, as important as it is, which is also about our collective economic well-being.

There is no alternative of a scientifically and technologically literate workforce as the future economy will also be science-based. Technology alone is not a magic bullet. Existing technologies can be adapted where necessary and new technologies can be invented when indicated, but the key to scientific success resides in human resources. Science education needs to suit today's world and there is a 'genuine mood for change' across all sectors. If Bangladesh hopes to eliminate poverty and provide a reasonable standard of living for its people, the government will have to invest heavily in scientific R\&D (Haider \& Sarker, 2012). For that, we also need to re-imagine science education, accepting a shift that is occurring and must occur in the way we think of its nature and purposes. More bottlenecks may crop up. We are to face and remove them step by step. Sincere and resolute efforts will help the nation reach the desired goal. Our scholars should be engaged in cutting-edge research at the frontier of S\&T. As such sense of competition and plenty of incentives should be there to motivate them. 


\section{REFERENCES}

Aikenhead, G. (2001), "Students Ease in Crossing Cultural Borders into School Science", Science Education, 85(2), 180-188.

Akhter, S. T. (2011), "Curriculum Emphases of Secondary Science Education”, preliminary findings of a Ph.D. work, Monash University, Australia.

Alam, G. M. (2008a), "The Role of Technical and Vocational Education in National Development of Bangladesh", Asia-Pacific Journal of Cooperative Education, 9(1), 25-44.

Alam, G. M. (2008b), "Impact of the Private Universities on Bangladeshi Education System: An Investigation on Education Policy", VDM, Germany.

Alam, G. M. (2009) ," The role of science and technology education at network age population for sustainable development of Bangladesh through human resource advancement", available at: https://pdfs.semanticscholar.org/dfbd/b129618b19b7082d3383c45612178027bfd4.pdf (accessed 28 July 2019)

Alam, G. M. and Khalifa, M. T. B. (2009), "The Impact of Introducing a Business Marketing Approach to Education: A Study on Private HE in Bangladesh", African Journal of Business Management, 3(9): 463-474.

Althusser, L. (1971), Lenin and Philosophy and Other Essays, New Left Books, London.

Ashraf, S. (2008), "State of Science Education in Bangladesh Current Status and Future Trends", Star Campus, Volume 2, Issue 79, July 27, 1.

BANBEIS-Educational Database, "Bangladesh Education Statistics 2018(New)", available at: http:/ / data.banbeis.gov.bd/images/ban004.pdf (accessed 18 June 2019)

Billah, M. (2012), "Now Is the Time to Think of Quality Education and Drop out?", available at: https:/ / bdeduarticle.com/now-is-the-time-to-think-of-quality-education-and-drop-out (accessed 28 July 2019)

CAMPE (2011), "Education Watch 2009-10: Exploring Low Performance in Education - The Case of Sylhet Division", Dhaka, Bangladesh.

Chadwick, Bruce A., et al. (1984), Social Science Research Methods, Prentice-Hall, New Jersey.

Choudhury, S. K. (2009), "Problems and Prospects of Science Education in Bangladesh", AIP Conference Proceedings (Third IUPAP International Conference on Women in Physics),2007, Volume $1119,83-84$.

CPD (2011), Dialogue on State of the Bangladesh Economy Analysis of the National Budget FY2011-12, 18 June, Dhaka.

Dhaka Tribune, (2019) "Education sector to see increase of Tk13, 213cr", 13 June, 1. Available at: https://www.dhakatribune.com/bangladesh/2019/06/13/education-sector-to-see-increase-oftk13-213cr (accessed 24 July 2019)

Forsyth, Ian, et al. (1995), Planning a Course: Practical Strategies for Teachers, Lecturers and Trainers, Kogan Page, London.

Haider, Q. and Sarker, S. K. (2012), "Science cannot Coexist with Backwardness", The Daily Star, 7 August.

Kaykobad, M. (2012), "Popularising Science Education", FORUM, Vol. 6, No. 9. available at: https://archive.thedailystar.net/forum/2012/September/popularising.htm (accessed 10 May 2018)

Miah, M. B. (2011), "Current Situations of Basic Education in Bangladesh", available at: http:/ / www.criced.tsukuba.ac.jp/pdf/06_Bangladesh_Badal.pdf (accessed 20 June 2018)

Ministry of Education (2017), Bangladesh Education Statistics 2016, BANBEIS, Bangladesh. 
Ministry of Planning (2018), Bangladesh Statistics 2018, Bangladesh Bureau of Statistics (BBS), Bangladesh.

Sarkar, M. M. (2011), "Promoting Scientific Literacy through Secondary Science Textbooks", preliminary findings of a Ph.D. work, Monash University, Australia.

Siddique, M. N. A. and Rahman, S. M. H. (2007), "Introducing open investigation in secondary science practical work: Prospects and challenges in the context of Bangladesh", Teacher's World Journal of Education and Research, 19-33.

Subramanian .R (2002), "Gender and Education", available at: https:/ / www.files.ethz.ch/isn/102710/9.pdf (accessed 28 July 2019)

The Daily Star (2019), "Budget 2019-20 in pie charts", 13 June, 1 available at: https:/ / www.thedailystar.net/bangladesh-national-budget-2019-20/bangladesh-budget-201920-in-pie-charts-1756573 (accessed 24 July 2019)

UNESCO (2008), EFA Global Monitoring Report, Oxford University Press, New York.

UNICEF (2011), “Child-Friendly Schools", available at: http://www.unicef.org/lifeskills /index_7260.html (accessed 12 February 2018).

Zanken, J. W. V. (1985), Human Development, $3^{\text {rd }}$ edition, Alfred A. Knopf, New York.

Ziman, J. (2000), Real Science: What it is, and What it Means, Cambridge University Press, New York. 